\title{
Comparative photodynamic therapy study using two phthalocyanine derivatives
}

\author{
EDITH INÉS YSLAS ${ }^{1,2^{*}}$, LAURA NATALIA MILLA ${ }^{1 *}$, SILVIA ROMANINI $^{3}$, EDGARDO NÉSTOR DURANTINI $^{2}$, \\ MABEL BERTUZZI $^{1}$ and VIVIANA ALICIA RIVAROLA ${ }^{1}$
}

Departments of ${ }^{1}$ Molecular Biology, ${ }^{2}$ Chemistry, and ${ }^{3}$ Animal Pathology,

Universidad Nacional de Río Cuarto, X580BYA Río Cuarto, Argentina

Received February 22, 2010; Accepted April 30, 2010

DOI: $10.3892 /$ etm_00000110

\begin{abstract}
In the present study, a comparative photodynamic therapy (PDT) study was performed using the phthalocyanine derivatives, $\mathrm{ZnPc}\left(\mathrm{OCH}_{3}\right)_{4}$ and $\mathrm{ZnPc}\left(\mathrm{CF}_{3}\right)_{4}$, in a mouse tumor model, under identical experimental procedures. We studied the ablation of tumors induced by PDT. The end-point was to compare the photodynamic efficacy of $\mathrm{ZnPc}\left(\mathrm{OCH}_{3}\right)_{4}$ and $\mathrm{ZnPc}\left(\mathrm{CF}_{3}\right)_{4} . \mathrm{ZnPc}\left(\mathrm{OCH}_{3}\right)_{4}$ and $\mathrm{ZnPc}\left(\mathrm{CF}_{3}\right)_{4}$ were administered intraperitoneally at a dose of $0.2 \mathrm{mg} / \mathrm{kg}$ body weight. The injections of drugs were carried out in Balb/c mice bearing subcutaneously inoculated LM2 mouse mammary adenocarcinoma. Histological examination and serum biochemical parameters were used to evaluate hepatic and renal toxicity and function. Phototherapeutic studies were achieved employing a light intensity of $210 \mathrm{~J} / \mathrm{cm}^{2}$. After PDT, tumoral regression analyses were carried out, and the degree of tumor cell death was measured utilizing the vital stain Evan's blue. In this pilot study, we revealed that the cytotoxic effect of $\mathrm{ZnPc}\left(\mathrm{OCH}_{3}\right)_{4}$ after PDT led to a higher success rate compared to $\mathrm{ZnPc}\left(\mathrm{CF}_{3}\right)_{4}$-PDT when both were intraperitoneally injectioned. Both phthalocynanine derivatives were able to induce ablation in the tumors. In summary, these results demonstrate the feasibility of $\mathrm{ZnPc}\left(\mathrm{OCH}_{3}\right)_{4}$ - or $\mathrm{ZnPc}\left(\mathrm{CF}_{3}\right)_{4}-\mathrm{PDT}$ and its potential as a treatment for small tumors.
\end{abstract}

Correspondence to: Dr Edith Inés Yslas or Dr Viviana Alicia Rivarola, Departamento de Biología Molecular, Universidad Nacional de Río Cuarto, Agencia Postal Nro 3, X580BYA Río Cuarto, Argentina

E-mail: eyslas@exa.unrc.edu.ar; vrivarola@exa.unrc.edu.ar

${ }^{*}$ Conributed equally

Abbreviations: bw, body weight; DMEM, Dulbecco's modified Eagle's medium; ERS, endothelial-reticulum system; GPT, glutamic-pyruvic transaminase; H\&E, hematoxylin and eosin; HDL, high-density lipoproteins; i.p., intraperitoneally; LDL, low-density lipoproteins; PCs, phthalocyanines; PDT, photodynamic therapy; PS, photosensitizer; VLDL, very low-density lipoproteins

Key words: cancer, photodynamic therapy, phthalocyanines, tumor

\section{Introduction}

Photodynamic therapy (PDT) is a well-known procedure in the field of clinical medicine for the treatment of cancer, although there has also been research into its application for non-malignant disorders, such as psoriasis or actinic keratosis and for cases of choroidal neovascularization.

The treatment is currently under active investigation for palliative or curative applications. PDT is an evolving cancer treatment that depends on three known and variable components: photosensitizer (PS), light and oxygen (1). PDT relies on selective accumulation of a PS in tumor tissue, which on illumination with light of appropriate wavelengths, generates reactive oxygen species, particularly singlet oxygen, and destroys tumor tissue (2). In recent years, treatment of cancer by PDT has gained considerable interest due to its intrinsic dual selectivity. The PS localizes in the malignant tissue, and the light is spatially focused on the lesion (3). Phthalocyanines (PCs) are PSs of the dye family. PCs and their derivatives have been intensively investigated as the second generation PSs for PDT (4). Most of the activity of clinical PSs in the dye family comes from phthalocyanines and their relatives, the naphthalocyanines. These structures are active in a range of $650-850 \mathrm{~nm}$. Most dyes are hydrophobic requiring delivery agents, such as a liposomal preparation, for clinical use. Linking dyes to a variety of metals improves efficacy. Aluminum, zinc and silicon appear to offer the best PDT activity (5).

The development of new compounds as potential PSs in PDT is of great scientific interest. The advantage of this therapy over available therapies is the high selectivity of tumor destruction and the minimum damage to normal tissues. PDT kills tumor cells by destruction of vascular endothelium and/ or direct tumor cell kill. This treatment destroys cells by either apoptotic or necrotic cell death (6).

In this study, a comparative PDT analysis was carried out administrating two phthalocyanine derivatives, $\mathrm{ZnPc}\left(\mathrm{OCH}_{3}\right)_{4}$ and $\mathrm{ZnPc}\left(\mathrm{CF}_{3}\right)_{4}$, in a mouse tumor model.

\section{Materials and methods}

Photosensitizers. Zinc (II) 2,9,16,23-tetrakis (4-trifluoromethylbenzyloxy) phthalocyanine $\left[\mathrm{ZnPc}\left(\mathrm{CF}_{3}\right)_{4}\right]$ and zinc (II) 
2,9,16,23-tetrakis (methoxy) phthalocyanine $\left[\mathrm{ZnPc}\left(\mathrm{OCH}_{3}\right)_{4}\right]$ were synthesized as described by Yslas et al (7).

Animal model. Female Balb/c mice were obtained from the Fundación Balseiro, Buenos Aires, Argentina. At the start of the experiments, the mice were 7 to 8 weeks old, with an average body weight of 20-25 g. Three mice were housed per cage in a room with constant temperature $\left(24-26^{\circ} \mathrm{C}\right)$ and humidity (30-50\%). The dark/light cycles were $12 / 12 \mathrm{~h}$. The animals were given free access to regular chow pellets and water. All animals used in this study were handled in strict adherence to ethical care according to the guidelines established by the ANMAT Disposition N. 6344/96, pp1-7 for Human Care of Experimental Animals. The mice were closely monitored daily for signs of pain and distress by evaluating appetite, hydration status and activity level.

Cells and tumor model. For the generation of the experimental tumors, mouse mammary adenocarcinoma cell line LM2 (obtained from Hospital Roffo, Buenos Aires, Argentina) was used. The LM2 cell line was maintained in a humidified 5\% $\mathrm{CO}_{2}$ atmosphere at $37^{\circ} \mathrm{C}$ using Dulbecco's modified Eagle's medium (DMEM) suplemented with $10 \%$ fetal bovine serum and $1 \%$ penicillin-streptomycin solution. The LM2 cells $\left(1 \times 10^{6}\right)$ were suspended in $0.1 \mathrm{ml}$ of phosphate-buffered saline (pH 7.0) and subcutaneously injected into the right flanks in the depilated dorsal region of the mice.

When the tumor size reached $7 \mathrm{~mm}$ on the outer diameter, tumoral propagation was carried out extracting $2 \mathrm{~mm}$ of tumoral tissue which was subcutaneously re-implanted into the dorsal region of the desired number of mice for each experiment.

Tumor growth was documented regularly by external measurements with electronic calipers.

No spontaneous regression of the tumor was observed during our investigations.

When required, animals were anaesthetized using an intraperitoneal (i.p.) injection of a mixture of ketamine hydrochloride [Ketaject; Phoenix Pharmaceutical, St. Joseph, MO, USA; $50 \mathrm{mg} / \mathrm{kg}$ body weight (bw), Acedan (Holliday-Scott, SA, Buenos Aires, Argentina; $17 \mathrm{mg} / \mathrm{kg}$ bw) and xylazine hydrochloride (Bayer, Shawnee Mission, KS, USA; $5 \mathrm{mg} / \mathrm{kg}$ bw).

Irradiation. For the phototherapeutic studies, tumors were irradiated employing a Kodak projector equipped with a 150-W lamp. The light was filtered through a $3-\mathrm{cm}$ water layer to absorb the heat. A wavelength of range $350-800 \mathrm{~nm}$ was selected with the aid of optical filters. The diameter of the light in the treatment site was $1 \mathrm{~cm}$. This area was obtained by making a hole in a Tergopol layer, which finally isolated the mouse body. Light intensity at the treatment site was $210 \mathrm{~J} /$ $\mathrm{cm}^{2}$ (Radiometer Laser Mate-Q, Coherent, Hilton, Australia).

Hepatic and renal function. In order to determine the toxicity of $\mathrm{ZnPc}\left(\mathrm{CF}_{3}\right)_{4}$ and $\mathrm{ZnPc}\left(\mathrm{OCH}_{3}\right)_{4}$, physiological tests were performed employing the following diagnostic kits (obtained from Weiner Laboratories, SAIC, Rosario, Argentina): direct creatinine, uremia and transaminase GPT 200. Mice were sacrificed by cervical dislocation at $1(n=5), 7(n=5)$ and 30 days $(n=5)$ after injection of the phthalocyanine deriva- tives $\mathrm{ZnPc}\left(\mathrm{CF}_{3}\right)_{4}$ and $\mathrm{ZnPc}\left(\mathrm{OCH}_{3}\right)_{4}(0.2 \mathrm{mg} / \mathrm{kg} \mathrm{bw})$, and blood was extracted to obtain the serum for the functionality tests. To evaluate hepatic function, the levels of serum enzyme glutamic-pyruvic transaminase (GPT) were measured, since high levels in serum of GPT generally are associated with hepatotoxicity. Kidney function was monitored by measuring the serum levels of creatinine and urea.

Dark toxicity and histopathology examination. $\mathrm{ZnPc}\left(\mathrm{CF}_{3}\right)_{4}$ and $\mathrm{ZnPc}\left(\mathrm{OCH}_{3}\right)_{4}$ in $\mathrm{D}, \mathrm{L}-\alpha$-dipalmitoyl phosphatidylethanolamina liposome $(0.2 \mathrm{mg} / \mathrm{kg}$ bw) were administered by i.p. injection. The animals were placed in metabolic cages in the dark, and 5 mice were sacrificed after $\mathrm{ZnPc}\left(\mathrm{CF}_{3}\right)_{4}$ or $\mathrm{ZnPc}\left(\mathrm{OCH}_{3}\right)_{4}$ administration for histological examination. Seven days after injection, internal organs, such as the liver, kidney and spleen, were excised, fixed in $4 \%$ formaldehyde and embedded in paraffin. Blocks were sectioned $(3-\mu \mathrm{m})$ and stained with H\&E for microscopical analysis.

The histopathological analysis was carried out in the Animal Pathology Department of Agronomy and Veterinary Faculty, UNRC, under the supervision of Silvia Romanini.

\section{Phototherapeutic studies}

Tumor regression. After PDT, tumor regression analysis was performed. Tumor growth was documented regularly by external measurements with electronic calipers. The tumor size was assessed by taking three caliper measurements at right angles to each other and by applying the following formula: $\mathrm{V}=(\mathrm{L} \times \mathrm{W} \times \mathrm{H} \times 0.5636)$, where $\mathrm{L}$ is the length, $\mathrm{W}$ is the width and $\mathrm{H}$ is the height of the tumor $(8,9)$.

The effectiveness of the treatment was evaluated by comparing the rate of tumor growth of the mice treated with $\mathrm{ZnPc}\left(\mathrm{CF}_{3}\right)_{4}$ or $\mathrm{ZnPc}\left(\mathrm{OCH}_{3}\right)_{4}$ and irradiated with that observed for the control mice treated only with $\mathrm{ZnPc}\left(\mathrm{CF}_{3}\right)_{4}$ or $\mathrm{ZnPc}\left(\mathrm{OCH}_{3}\right)_{4}$, the control-light [without $\mathrm{ZnPc}\left(\mathrm{CF}_{3}\right)_{4}$ or $\mathrm{ZnPc}\left(\mathrm{OCH}_{3}\right)_{4}$ but with tumor irradiation] and the controlcontrol [without $\mathrm{ZnPc}\left(\mathrm{CF}_{3}\right)_{4}$ or $\mathrm{ZnPc}(\mathrm{OCH} 3) 4$ and without tumor irradiation] mice.

Degree of tumor necrosis. The degree of tumor necrosis was measured utilizing the vital stain Evan's blue (10). This dye reflects the mechanism of tumor destruction (11). To determine the phototherapeutic effect of the phthalocyanine derivatives, the degree of tumor necrosis was assessed after PDT following this technique (10). Vital stain was performed by i.p. injection of $0.4 \mathrm{ml} 1 \%$ solution. This was injected into the mice of the different groups: control-control $(n=4)$, control-light $(\mathrm{n}=4), \mathrm{ZnPc}\left(\mathrm{CF}_{3}\right)_{4}$-dark [with $\mathrm{ZnPc}\left(\mathrm{CF}_{3}\right)_{4}$, but without tumor irradiation] $(\mathrm{n}=4), \mathrm{ZnPc}\left(\mathrm{OCH}_{3}\right)_{4}$-dark [with $\mathrm{ZnPc}\left(\mathrm{OCH}_{3}\right)_{4}$, but without tumor irradiation] ( $\mathrm{n}=4), \mathrm{ZnPc}\left(\mathrm{CF}_{3}\right)_{4}$-light [with $\mathrm{ZnPc}\left(\mathrm{CF}_{3}\right)_{4}$ and tumor irradiation] $(\mathrm{n}=7)$ and $\mathrm{ZnPc}\left(\mathrm{OCH}_{3}\right)_{4^{-}}$ light [with $\mathrm{ZnPc}\left(\mathrm{OCH}_{3}\right)_{4}$ and tumor irradiation] $(\mathrm{n}=6)$.

After 1, 4 and 10 days post-PDT, the animals were injected with Evan's blue, and then, $6 \mathrm{~h}$ post-administration (to permit distribution of the dye) the animals were sacrificed. The tumors were excised, and 2- to 3-mm cross-section slices were cut. The tumors were examined macroscopically and photographed using a magnification glass (x4) and analyzed using an image analyzer (Motic Images Plus). The tumor sections were examined microscopically in planes corresponding to the image plane. The unstained area was considered to be 


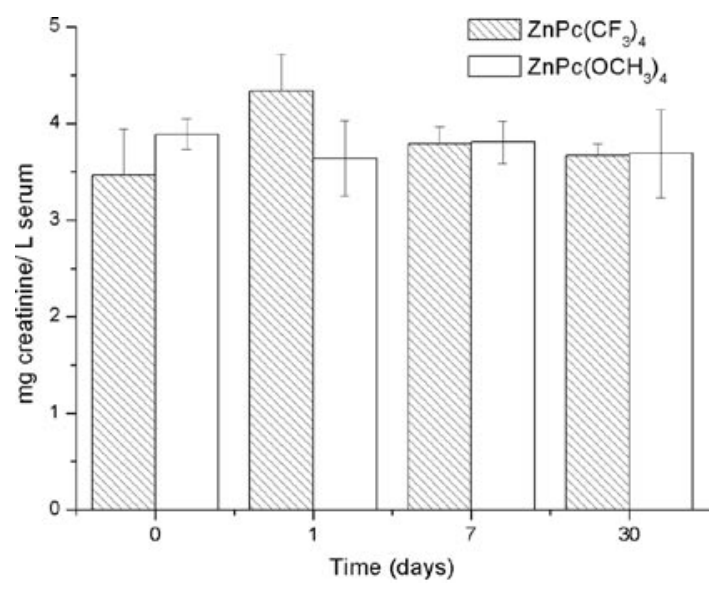

Figure 1. Serum concentration of creatinine in the control group, 1, 7 and 30 days after $\mathrm{ZnPc}\left(\mathrm{CF}_{3}\right)_{4}$ or $\mathrm{ZnPc}\left(\mathrm{OCH}_{3}\right)_{4}$ injection $(0.2 \mathrm{mg} / \mathrm{kg}$ bw). Data represent the means $\pm \operatorname{SEM}(\mathrm{n}=5)$. ${ }^{\mathrm{p}}<0.05$

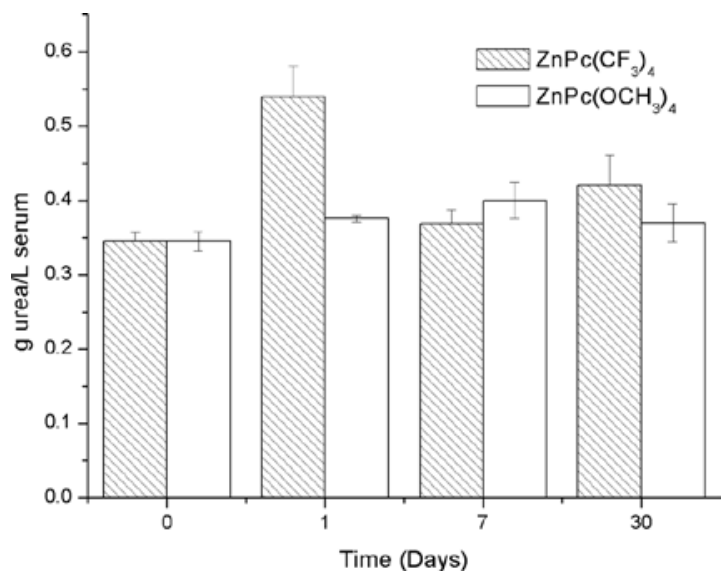

Figure 2. Serum concentration of urea in the control group, 1, 7 and 30 days after $\mathrm{ZnPc}\left(\mathrm{CF}_{3}\right)_{4}$ or $\mathrm{ZnPc}\left(\mathrm{OCH}_{3}\right)_{4}$ injection $(0.2 \mathrm{mg} / \mathrm{kg}$ bw). Data represent the means \pm SEM $(n=5)$. ${ }^{*}<0.05$.

necrotic tissue, whereas the stained area was tissue with a preserved blood supply. In addition, the histological sections of the tumors were obtained as described above.

Tumor histological examination. The animals were sacrificed after 10 days. Tumor samples from the tumor-regressed mice and control tumor-bearing mice (tumor samples before PDT) were excisioned and fixed in $10 \%$ formalin for routine histological preparation. The representative tissues were dehydrated in ascending grades of alcohol, embedded in paraffin wax, and sections (3- to $4-\mu \mathrm{m}$ ) were obtained. The tissue sections were stained with $\mathrm{H} \& \mathrm{E}$ and examined under a microscope (Axiovert 135; Zeiss, Germany). The images were recorded using a digital color camera (Axiocam; Zeiss) and Axiovision 4.3 software.

Tumor sections were stained with H\&E to identify the areas of viable and necrotic tissue. All experiments were repeated at least three times.

Statistics. Statistical comparisons were performed using ANOVA. The Duncan test was used when appropriate post hoc comparison was possible, and a value of $\mathrm{p}=0.05$ was considered significant. Data are expressed as mean \pm SEM,

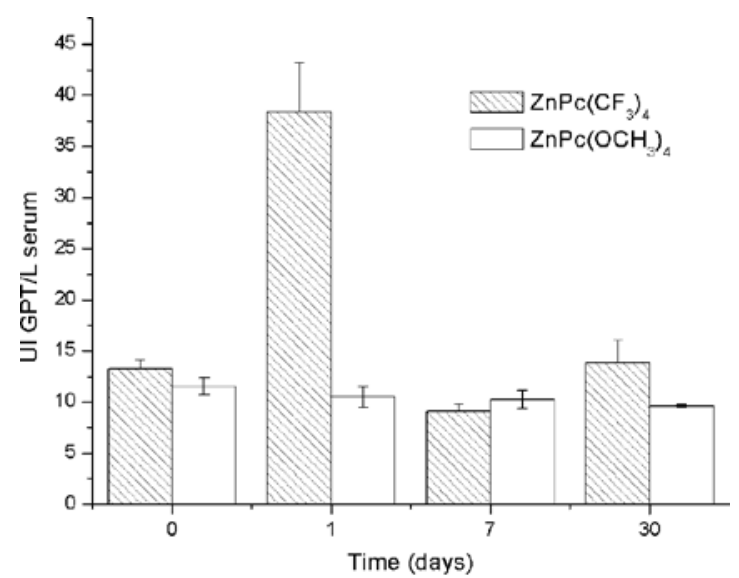

Figure 3. Serum concentration of GPT in the control group, 1, 7 and 30 days after $\mathrm{ZnPc}\left(\mathrm{CF}_{3}\right)_{4}$ or $\mathrm{ZnPc}\left(\mathrm{OCH}_{3}\right)_{4}$ injection $(0.2 \mathrm{mg} / \mathrm{kg}$ bw). Data represent the means $\pm \operatorname{SEM}(n=5) .{ }^{*} \mathrm{p}<0.05$.

and differences between means were considered statistically significant at $\mathrm{p}<0.05$.

\section{Results}

Hepatic and renal function. No pathological damage was observed in the liver and kidney of mice treated with $\mathrm{ZnPc}\left(\mathrm{OCH}_{3}\right)_{4}(0.2 \mathrm{mg} / \mathrm{kg} \mathrm{bw})$. Also, there were no differences in creatinine, urea and GPT serum concentration among the control mice, 1,7 and 30 days post-injection of $\mathrm{ZnPc}\left(\mathrm{OCH}_{3}\right)_{4}$ $(0.2 \mathrm{mg} / \mathrm{kg}$ bw) (Figs. 1, 2 and 3, respectively). These results suggest that $\mathrm{ZnPc}\left(\mathrm{OCH}_{3}\right)_{4}$ does not cause adverse effects in mice. In contrast, statistical analysis did not show a significant difference in the creatinine serum concentration among the control mice, 1, 7 and 30 days post-injection of $\mathrm{ZnPc}\left(\mathrm{CF}_{3}\right)_{4}$ $(0.2 \mathrm{mg} / \mathrm{kg}$ bw) (Fig. 1). Nevertheless, significantly high levels of uremia in mice on the first day post-injection with respect to the controls were observed. There were no significant differences 7 and 30 days post-injection compared to the controls (Fig. 2).

Significantly high levels of GPT serum concentration were observed 1 day post-injection in relation to the controls. However, normal values of GPT were noted 7 and 30 days post-injection (Fig. 3). This indicates that adverse effects were significantly observed at $24 \mathrm{~h}$ post-administration in levels of uremia and GPT, but these values returned to normal. The dose of $0.2 \mathrm{mg} / \mathrm{kg}$ bw of $\mathrm{ZnPc}\left(\mathrm{CF}_{3}\right)_{4}$ did not produce time-persistent toxicity, thus it is suitable for administration in PDT.

Histopathological examination. Tissues 10 days after PDT were obtained immediately after euthanasia for histopathologic examination. On the other hand, the tumors were removed 10 days after PDT using $\mathrm{ZnPc}\left(\mathrm{OCH}_{3}\right)_{4}$ and $\mathrm{ZnPc}\left(\mathrm{CF}_{3}\right)_{4}$.

On the basis of the pharmacokinetic data, histological examinations were performed in the liver and kidney. In these organs, $\mathrm{ZnPc}\left(\mathrm{CF}_{3}\right)_{4}$ administration resulted in a slight acute toxicity. Its adverse affects were reverted at 7 days postinjection. Histological damage was not found 10 days after the administration of $\mathrm{ZnPc}\left(\mathrm{OCH}_{3}\right)_{4}$ using the same dose as $\mathrm{ZnPc}\left(\mathrm{CF}_{3}\right)_{4}$. This result indicates that both drugs are suitable for use in PDT at the dose of $0.2 \mathrm{mg} / \mathrm{kg}$ bw, as they do not produce irreversible damage (Fig. 4). 


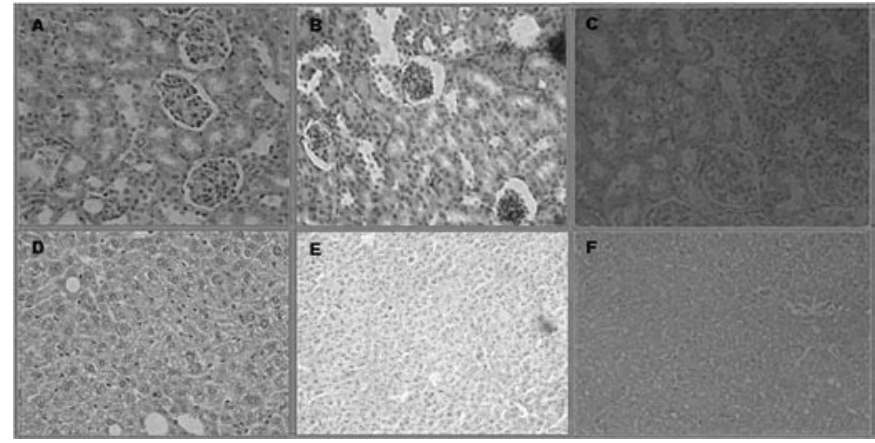

Figure 4. Microscopic image of a kidney from (A) a control mouse, (B) a mouse 10 days after treatment with $\mathrm{ZnPc}\left(\mathrm{OCH}_{3}\right)_{4}(0.2 \mathrm{mg} / \mathrm{kg}$ bw), and $(\mathrm{C})$ a mouse 10 days after treatment with $\mathrm{ZnPc}\left(\mathrm{CF}_{3}\right)_{4}(0.2 \mathrm{mg} / \mathrm{kg} \mathrm{bw})$. Microscopic image of liver obtained from (D) a control mouse, (E) a mouse 10 days after treatment with $\mathrm{ZnPc}\left(\mathrm{OCH}_{3}\right)_{4}(0.2 \mathrm{mg} / \mathrm{kg}$ bw), and $(\mathrm{F})$ a mouse 10 days after treatment with $\mathrm{ZnPc}\left(\mathrm{CF}_{3}\right)_{4}(0.2 \mathrm{mg} / \mathrm{kg}$ bw) (magnification $\mathrm{x} 400)$. The specimens were stained with $\mathrm{H} \& \mathrm{E}$.

A

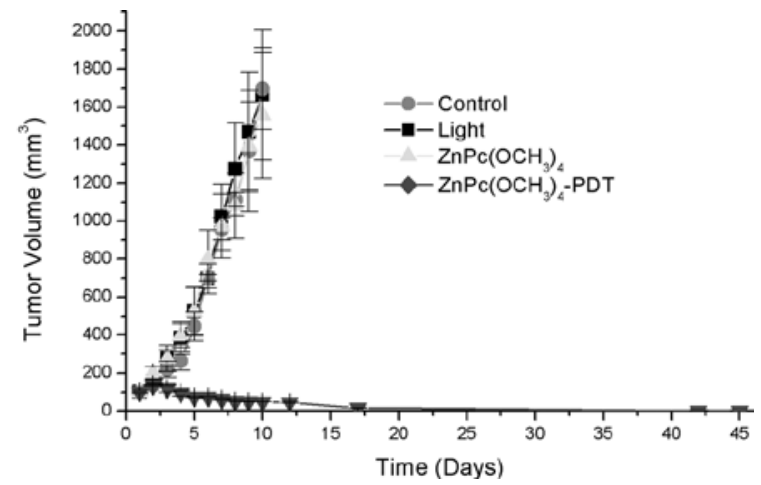

B

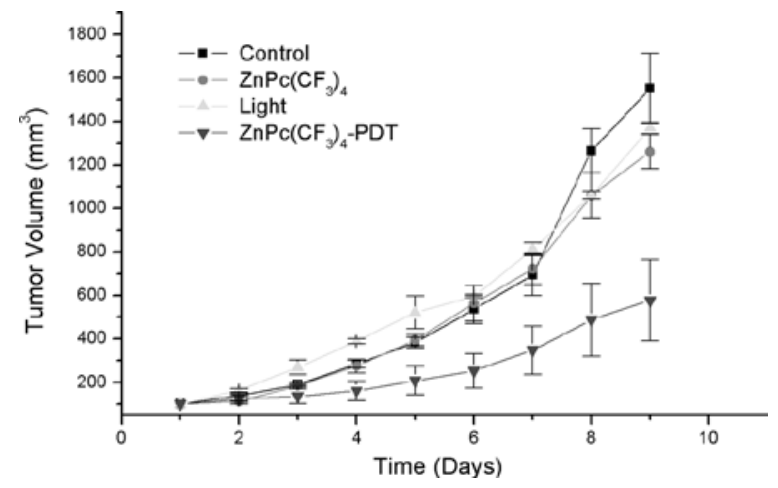

Figure 5. (A) Effect of $\mathrm{ZnPc}\left(\mathrm{OCH}_{3}\right)_{4}$-PDT or $\mathrm{ZnPc}\left(\mathrm{CF}_{3}\right)_{4}$ on tumors Tumors were either untreated or treated with $\mathrm{ZnPc}\left(\mathrm{OCH}_{3}\right)_{4}$ alone, light alone or $\mathrm{ZnPc}\left(\mathrm{OCH}_{3}\right)_{4}$-PDT, with light doses of $210 \mathrm{~J} / \mathrm{cm}^{2}$. (B) Effect of $\mathrm{ZnPc}\left(\mathrm{CF}_{3}\right)_{4}$-PDT on tumors. Tumors were either untreated or treated with $\mathrm{ZnPc}\left(\mathrm{CF}_{3}\right)_{4}$ alone, light alone or $\mathrm{ZnPc}\left(\mathrm{CF}_{3}\right)_{4}-\mathrm{PDT}$, with light doses of $210 \mathrm{~J} /$ $\mathrm{cm}^{2}$ (B). Data represent the means \pm SEM of the volumes of 8 tumors in each experimental group.

Significant differences were not found at the histological level of the kidney, liver and spleen between control mice and mice sacrificed 7 days after injection of $\mathrm{ZnPc}\left(\mathrm{CF}_{3}\right)_{4}$ or $\mathrm{ZnPc}\left(\mathrm{OCH}_{3}\right)_{4}(0.2 \mathrm{mg} / \mathrm{kg}$ bw $)$.

\section{Phototherapeutic study}

Tumor regression. No differences in tumor volume were noted between the control and control irradiated with $210 \mathrm{~J} /$

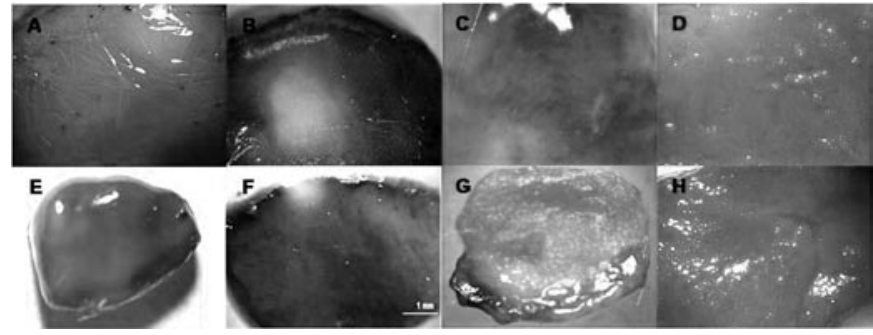

Figure 6. Transverse tumor sections of mice injected with the vital stain Evan's blue. A control $\mathrm{ZnPc}\left(\mathrm{OCH}_{3}\right)_{4}$-dark mouse (A), and mice treated with PDT and injected with Evan's blue 1 day post-PDT (B), 4 days post-PDT (C), and 10 days post-PDT (D). A control $\mathrm{ZnPc}\left(\mathrm{CF}_{3}\right)_{4}$-dark mouse (E) and mice treated with PDT injected with Evan's blue 1 day post-PDT (F), 4 days post-PDT $(\mathrm{G})$, and 10 days post-PDT $(\mathrm{H})$

$\mathrm{cm}^{2}$ and the mice treated with $\mathrm{ZnPc}\left(\mathrm{OCH}_{3}\right)_{4}$ or $\mathrm{ZnPc}\left(\mathrm{CF}_{3}\right)_{4}$ in the dark. Light alone or sensitizers alone had no effect on the growth of tumors. Compared to the control group, the growth of the implanted tumors was significantly inhibited with reduced tumor volumes after PDT. On the other hand, there were obvious differences between $\mathrm{ZnPc}\left(\mathrm{OCH}_{3}\right)_{4}$-PDT or $\mathrm{ZnPc}\left(\mathrm{CF}_{3}\right)_{4}-\mathrm{PDT}$ and the control groups regarding tumor size throughout the observation period (Fig. 5A and B, respectively).

Degree of tumor necrosis. In tumors of the control-control, control-light, $\mathrm{ZnPc}\left(\mathrm{CF}_{3}\right)_{4}$-dark and $\mathrm{ZnPc}\left(\mathrm{OCH}_{3}\right)_{4}$-dark groups, total staining with Evan's blue was observed, indicating that tumor death did not occur (Fig. 6A, B and C, respectively).

The area of tumor necrosis was measured by Evan's blue dye staining at 1, 4 and 10 days post-PDT.

Mice administered Evan's blue 1 day after PDT using $\mathrm{ZnPc}\left(\mathrm{CF}_{3}\right)_{4}$ exhibited a percentage of tumor death of $12 \%$, but when $\mathrm{ZnPc}\left(\mathrm{OCH}_{3}\right)_{4}$ was used, the tumor death percentage was $8.4 \%$ with the same dose of irradiation $\left(210 \mathrm{~J} / \mathrm{cm}^{2}\right)$ and drug concentration $(0.2 \mathrm{mg} / \mathrm{kg}$ bw) (Fig. 6D and E). Four days post-PDT, the tumor death percentage was $89.4 \%$ when $\mathrm{ZnPc}\left(\mathrm{CF}_{3}\right)_{4}$ was used, while this percentage decreased to $71.5 \%$ using $\mathrm{ZnPc}\left(\mathrm{OCH}_{3}\right)_{4}$ (Fig. 6D and E). Ten days post-PDT, the tumor death percentage was $72.2 \%$ when $\mathrm{ZnPc}\left(\mathrm{CF}_{3}\right)_{4}$ was used, while this percentage increased to $72.8 \%$ with $\mathrm{ZnPc}\left(\mathrm{OCH}_{3}\right)_{4}$ (Fig. $6 \mathrm{~F}$ and G). After 10 days, the death percentage was the same for both drugs (72\%).

Thus, the untreated viable tumors stained blue, while the tumors post-PDT exhibited white areas and showed no evidence of stain uptake. This regression of necrosis was also supported by the drastic reduction in Evans blue incorporation, which was clearly evident as an unstained area.

Four of $10(40 \%)$ tumors exhibited complete regression 4 days post $\mathrm{ZnPc}\left(\mathrm{CF}_{3}\right)_{4}$-PDT, while 6 of $8(75 \%)$ tumors showed total regression 10 days post $\mathrm{ZnPc}\left(\mathrm{OCH}_{3}\right)_{4}$-PDT.

Tumor histological examination. The histological evaluation of the group of mice $(\mathrm{n}=5)$ treated at $210 \mathrm{~J} / \mathrm{cm}^{2}$ after injection with $\mathrm{ZnPc}\left(\mathrm{CF}_{3}\right)_{4}$ or $\mathrm{ZnPc}\left(\mathrm{OCH}_{3}\right)_{4}(0.2 \mathrm{mg} / \mathrm{kg} \mathrm{bw})$ showed tumors with few focal necrotic areas evident following PDT treatment in most mice (Fig. 7B and C, respectively). This tumor cell death was probably the direct result of PDT cell killing mechanisms. In contrast, tumor regression in the mouse groups treated with $\mathrm{ZnPc}\left(\mathrm{OCH}_{3}\right)_{4}$ or $\mathrm{ZnPc}\left(\mathrm{CF}_{3}\right)_{4}$ after 


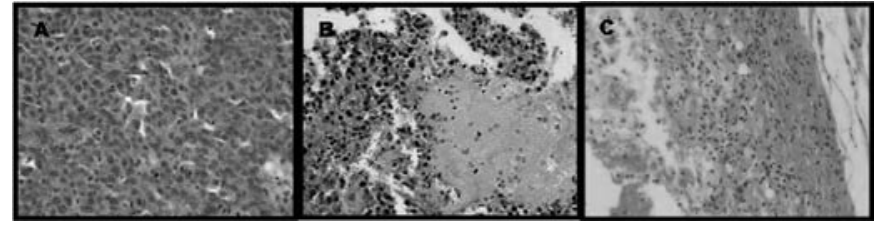

Figure 7. (A) H\&E-stained tumor specimen obtained after 10 days from the untreated group (magnification $\mathrm{x} 400$ ). The organization of the tumor tissue is well-preserved and typical for this tumor type. (B) H\&E-stained micrograph of a tumor 10 days after PDT with $0.2 \mathrm{mg} / \mathrm{kg}$ bw $\mathrm{ZnPc}\left(\mathrm{OCH}_{3}\right)_{4}$ by i.p. injection and light exposure of $210 \mathrm{~J} / \mathrm{cm}^{2}$. The micrograph (x400) shows a large area of cell death and ruptured vasculature. (C) H\&E-stained micrograph of a tumor 10 days after PDT using $0.2 \mathrm{mg} / \mathrm{kg}$ bw $\mathrm{ZnPc}\left(\mathrm{CF}_{3}\right)_{4}$ by i.p. injection and light exposure of $210 \mathrm{~J} / \mathrm{cm}^{2}$. The micrograph (x400) shows a large area of cell death.

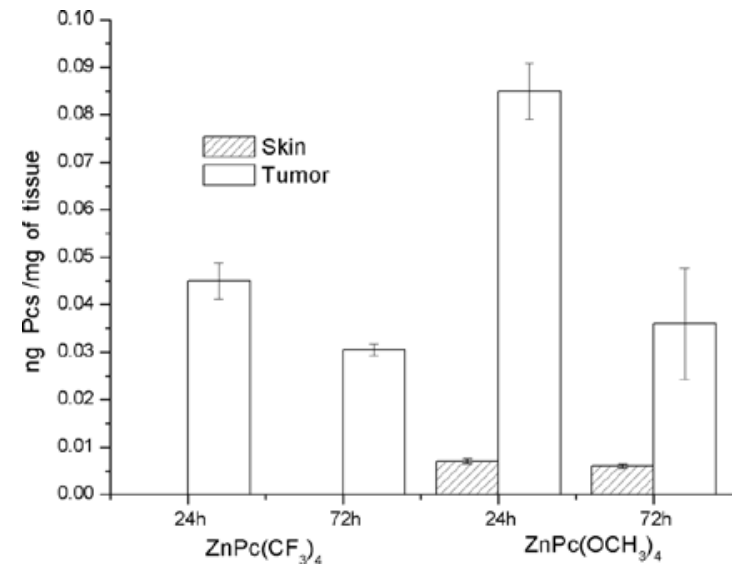

Figure 8. Tumor:skin ratio after injection of either $\mathrm{ZnPc}\left(\mathrm{OCH}_{3}\right)_{4}$ or $\mathrm{ZnPc}\left(\mathrm{CF}_{3}\right)_{4}$. Data represent the means $\pm \mathrm{SEM}$.

treatment of PDT was observed by a decrease in tumor volume (Fig. 5A and B, respectively).

In contrast, in tumors treated with $210 \mathrm{~J} / \mathrm{cm}^{2}$ alone, control and $\mathrm{ZnPc}\left(\mathrm{CF}_{3}\right)_{4}$ or $\mathrm{ZnPc}\left(\mathrm{OCH}_{3}\right)_{4}$ in dark condition, no significant effect on tissue damage and tumor growth was noted (Fig. 7A).

Tumor to skin ratio. Tumor uptake of a PS depends on hydrophobicity/hydrophilicity of the sensitizer.

Previous investigation has revealed that most of the liposome-released PSs are associated with high density lipoproteins (HDL), low density lipoproteins (LDL) and very low density lipoproteins (VLDL), whereas free PSs are distributed evenly between albumin and HDL (12). LDL-bound lipophilic PSs can be selectively incorporated into tumor cells, whereas hydrophilic PSs bind preferentially to serum albumin and often accumulate in the vascular stroma of tumors. It has been suggested that when liposomal PSs are administered to animals, the PS is more efficiently transferred to LDL than an aqueous formulation $(13,14)$.

In the present study, the $\mathrm{ZnPc}\left(\mathrm{OCH}_{3}\right)_{4}$ and $\mathrm{ZnPc}\left(\mathrm{CF}_{3}\right)_{4}$ concentrations in the tumors were at a maximum level $24 \mathrm{~h}$ after injection of 0.085 and $0.045 \mathrm{ng} / \mathrm{mg}$ tissue, respectively, and then the levels of both drugs decreased. The absolute amounts of $\mathrm{ZnPc}\left(\mathrm{OCH}_{3}\right)_{4}$ in the tumors were higher than that in the skin 24 or $72 \mathrm{~h}$ after i.p. injection. The tumor to skin accumulation ratio was 12.14 at $24 \mathrm{~h}$, and 6.0 at $72 \mathrm{~h}$ after the injection.

After 24 and $72 \mathrm{~h}$ post-injection of $\mathrm{ZnPc}\left(\mathrm{CF}_{3}\right)_{4}$ there was no accumulation in the skin (Fig. 8). The lower level of the drug in the skin is appropriated in tumor treatments since only a low cutaneous phototoxicity is found in experimental carcinoma models in vivo. Delivery of $\mathrm{ZnPc}\left(\mathrm{OCH}_{3}\right)_{4}$ or $\mathrm{ZnPc}\left(\mathrm{CF}_{3}\right)_{4}$ in liposomal solution gains access to cells in the tumor mass in a relatively short period of time and localizes with a high degree of specificity.

\section{Discussion}

The uptake, distribution and retention of a sensitizer in a tumor depend on the route and mode of delivery, as well as on the physicochemical properties (e.g., lipophilicity) of the drug. For instance, lipophilic PSs need to be incorporated into delivery vehicles, for example liposomes in in vivo administration. Liposomes are known to enhance the clinical effects of PSs, facilitate uptake by tumor cells due to direct contact of the liposomal drug with the tumor, reduce their toxicity and protect them from immune responses. The tumor cells express higher levels of receptors to the lipoprotein LDL than normal cells, facilitating entry of the drug into neoplastic cells. Both phthalocyanine derivatives $\left[\mathrm{ZnPc}\left(\mathrm{CF}_{3}\right)_{4}\right.$ and $\left.\mathrm{ZnPc}\left(\mathrm{OCH}_{3}\right)_{4}\right]$ exhibit lipophilic properties. The phthalocyanine derivative $\mathrm{ZnPc}\left(\mathrm{OCH}_{3}\right)_{4}$ exhibited a high lipophilic character which allowed it to remain in the tumor, improving the phototherapeutic action. Therefore, one factor which enhances the specificity of the PS for neoplastic tissues is its highly hydrophobic character. However, this characteristic leads to poor solubility of the molecules in physiologically compatible solvent media, and thus they must be administered in vivo by means of a delivery system (15). Various drug delivery systems, such as liposomes, polymeric micelles, Cremophor emulsion, microspheres and nanoparticles, have been developed to deliver PSs. Both phthalocyanine derivatives $\left[\mathrm{ZnPc}\left(\mathrm{CF}_{3}\right)_{4}\right.$ and $\left.\mathrm{ZnPc}\left(\mathrm{OCH}_{3}\right)_{4}\right]$ incorporated in liposomes containing cholesterol would probably favor interaction with the lipoprotein LDL and the accumulation in macrophages of RES and tumor tissue, which are known in the literature to have high expression of LDL receptors (16). This property confers enhanced efficiency to the phototherapeutic action, due to the fact that PSs can cross membranes and organelles interacting with intracellular proteins or structures that contains hydrophobic elements.

Both PSs did not affect the hepatic and renal function. The histological section of the treated tumors showed the presence of areas of necrosis and, in addition, demonstrated signs of inflammatory response; in addition, 10 days post-TFD the treated tumors showed signs of tumor death.

Tumor necrosis was achieved 10 days post-PDT at $24 \mathrm{~h}$ after i.p. injection of $\mathrm{ZnPc}\left(\mathrm{CF}_{3}\right)_{4}$ or $\mathrm{ZnPc}\left(\mathrm{OCH}_{3}\right)_{4}$. These results in vivo were confirmed by the use of Evan's blue dye. This dye is a direct and easy method for evaluating the mechanism of tumor destruction and measuring the depth of necrosis after PDT treatment. This method is suitable for assessing tumor death after PDT. 
One limiting factor for treatment success is the penetration depth of $\mathrm{ZnPc}\left(\mathrm{CF}_{3}\right)_{4}$.

While $\mathrm{ZnPc}\left(\mathrm{OCH}_{3}\right)_{4}$ was shown to penetrate more deeply, no highly significant difference in the therapeutic effect has been demonstrated so far. This result showed that $\mathrm{ZnPc}\left(\mathrm{OCH}_{3}\right)_{4}$ has more rapid clearance from the body tissue, particularly from the skin. In conclusion, our results demonstrate that $\mathrm{ZnPc}\left(\mathrm{CF}_{3}\right)_{4}$ and $\mathrm{ZnPc}\left(\mathrm{OCH}_{3}\right)_{4}$ accumulate in the tumor and that these sensitizers lead to tumor destruction upon photodynamic treatment.

\section{Acknowledgements}

The authors are grateful to Secretaría de Ciencia y Técnica (SECYT) of Universidad Nacional de Río Cuarto and Consejo Nacional de Investigaciones Científicas y Técnicas (CONICET) for financial support. E.I.Y., E.N.D. and V.A.R. are scientific members of CONICET.

\section{References}

1. Buytaert E, Dewaele M and Agostinis P: Molecular effectors of multiple cell death pathways initiated by photodynamic therapy. Review. Biochim Biophys Acta 1776: 86-107, 2007.

2. Henderson BW and Miller AC: Effects of scavengers of reactive oxygen and radical species on cell survival following photodynamic treatment in vitro: comparison to ionizing radiation. Radiat Res 108: 196-205, 1986.

3. Castano AP, Demidova TN and Hamblin MR: Mechanisms in photodynamic therapy: part three photosensitizer, pharmacokinetics, biodistribution, tumor localization and modes of tumor destruction. Photodiag Photodyn Therapy 2: 91-106, 2005.

4. Chan WS, Zuk $M$ and Ber-Hur E: Phthalocyanines. In Photodynamic Tumor Therapy, 2nd and 3rd Generation of Photosensitizers. Moser JG (ed). Harwood Academic, Amsterdam, pp63-73, 1998.

5. Allison R, Downie G, Cuenca R, Hu X, Childs C and Sibata C: Photosensitizers in clinical PDT. Photodiag Photodyn Therapy 1: 27-42, 2004.
6. Noodt BB, Berg K, Stokke T, Peng Q and Nesland JM: Different apoptotic pathways are induced from various intracellular sites by tetraphenylporphyrins and light. Br J Cancer 79: 72-81, 1999.

7. Yslas I, Rivarola V and Durantini EN: Synthesis and photodynamic activity of zinc (II) phthalocyanine derivatives bearing methoxy and trifluoromethylbenzyloxy substituents in homogeneous and biological media. Bioorg Med Chem 13: 39-46, 2005.

8. Whitacre CM, Feyes DK, Satoh T, Grossmann J, Mulvihill JW, Mukhtar $\mathrm{H}$ and Oleinik NL: Photodynamic therapy with the phthalocyanine photosensitizer Pc 4 of SW480 human colon cancer xenografts in athymic mice. Clin Cancer Res 6: 2021-2027, 2000.

9. Whitacre CM, Zborowska E, Willson JKV and Berger NA: Detection of poly (ADP-ribose) polymerase cleavage in response to treatment with topoisomerase I inhibitors: a potential surrogate end point to assess treatment effectiveness. Clin Cancer Res 5: 665-672, 1999.

10. Schastak S, Jean B, Handzel R, et al: Improved pharmacokinetics, biodistribution and necrosis in vivo using a new near infra-red photosensitizer: tetrahydroporphyrin tetratosylat. J Photochem Photobiol 78: 203-213, 2005.

11. Kostenich GA, Zhuravkin IN, Furmanchuk AV and Zhavrid EA: Photodynamic therapy with chlorin e6. A morphologic study of tumor damage efficiency in experiment. J Photochem Photobiol 11: 307-318, 1991.

12. Richter AM, Waterfield E, Jain AK, Canaan AJ, Allison BA and Levy JG: Liposomal delivery of a photosensitizer, benzoporphyrin derivative monoacid ring $\mathrm{A}$ (BPD), to tumor tissue in a mouse tumor model. Photochem Photobiol 57: 1000-1006, 1993.

13. Jori $G$ and Reddi $E$ : The role of lipoproteins in the delivery of tumour-targeting photosensitizers. Int J Biochem 25: 1369-1375, 1993.

14. Love WG, Havenaar EC, Lowe PJ and Peter WT: Uptake of zinc(II)-phthalocyanine by HepG2 cells expressing the low density lipoprotein receptor: studies with the liposomal formulation CGP55847. SPIE Proc 2078: 381-388, 1994.

15. Fadel M, Kassab K and Fadeel DA: Zinc phthalocyanine-loaded PLGA biodegradable nanoparticles for photodynamic therapy in tumor-bearing mice. Lasers Med Sci 25: 283-292, 2010

16. Polo L, Valduga G, Jori G and Redi E: Low-density lipoprotein receptors in the uptake of tumour photosensitizers by human and rat transformed fibroblasts. Int J Biochem Cell Biol 34: 10-23, 2002. 